\title{
The role of carbonyl sulphide as a source of stratospheric sulphate aerosol and its impact on climate
}

\author{
C. Brühl ${ }^{1}$, J. Lelieveld ${ }^{1,3}$, P. J. Crutzen ${ }^{1}$, and H. Tost ${ }^{2}$ \\ ${ }^{1}$ Atmospheric Chemistry Department, Max-Planck-Institute for Chemistry, Mainz, Germany \\ ${ }^{2}$ Institute for Physics of the Atmosphere, Johannes Gutenberg University, Mainz, Germany \\ ${ }^{3}$ The Cyprus Institute, Nicosia, Cyprus, and King Saud University, Riyadh, Saudi Arabia \\ Correspondence to: C. Brühl (christoph.bruehl@mpic.de)
}

Received: 9 June 2011 - Published in Atmos. Chem. Phys. Discuss.: 22 July 2011

Revised: 19 January 2012 - Accepted: 23 January 2012 - Published: 1 February 2012

\begin{abstract}
Globally, carbonyl sulphide (COS) is the most abundant sulphur gas in the atmosphere. Our chemistryclimate model (CCM) of the lower and middle atmosphere with aerosol module realistically simulates the background stratospheric sulphur cycle, as observed by satellites in volcanically quiescent periods. The model results indicate that upward transport of COS from the troposphere largely controls the sulphur budget and the aerosol loading of the background stratosphere. This differs from most previous studies which indicated that short-lived sulphur gases are also important. The model realistically simulates the modulation of the particulate and gaseous sulphur abundance in the stratosphere by the quasi-biennial oscillation (QBO). In the lowermost stratosphere organic carbon aerosol contributes significantly to extinction. Further, using a chemical radiative convective model and recent spectra, we compute that the direct radiative forcing efficiency by $1 \mathrm{~kg}$ of COS is 724 times that of $1 \mathrm{~kg} \mathrm{CO}$. Considering an anthropogenic fraction of $30 \%$ (derived from ice core data), this translates into an overall direct radiative forcing by $\mathrm{COS}$ of $0.003 \mathrm{~W} \mathrm{~m}^{-2}$. The direct global warming potentials of COS over time horizons of 20 and $100 \mathrm{yr}$ are $\operatorname{GWP}(20 \mathrm{yr})=97$ and $\operatorname{GWP}(100 \mathrm{yr})=27$, respectively (by mass). Furthermore, stratospheric aerosol particles produced by the photolysis of COS (chemical feedback) contribute to a negative direct solar radiative forcing, which in the CCM amounts to $-0.007 \mathrm{~W} \mathrm{~m}^{-2}$ at the top of the atmosphere for the anthropogenic fraction, more than two times the direct warming forcing of COS. Considering that the lifetime of COS is twice that of stratospheric aerosols the warming and cooling tendencies approximately cancel.
\end{abstract}

\section{Introduction}

The anthropogenic increase of greenhouse gases causes a radiative forcing of climate of more than $3 \mathrm{~W} \mathrm{~m}^{-2}$ (IPCC, 2007). Conversely, aerosol particles backscatter solar radiation and their anthropogenic emissions exert a global mean negative radiative forcing of about $-0.5 \mathrm{~W} \mathrm{~m}^{-2}$, being enhanced by a factor of two or more by indirect effects of the particles on clouds (IPCC, 2007). The anthropogenic aerosol fraction is made up of sulphates, nitrates, organics and black carbon that are continually produced by the use of fossil fuels, biomass burning and agricultural practices. On shorter timescales volcanoes can be an important contributor to tropospheric and stratospheric aerosol loadings. Occasionally strong explosive volcano eruptions can release large quantities of sulphur dioxide $\left(\mathrm{SO}_{2}\right)$ into the atmosphere. Especially if the volcanic $\mathrm{SO}_{2}$ is lofted to high altitudes in the tropics a substantial fraction can reach the stratosphere where it is converted into sulphate particles that also exert a negative radiative forcing. The strongest volcano eruption in the past century was of Mt. Pinatubo in June 1991. Satellite data have shown that about 10 million tonnes of sulphur (Mt S) reached the stratosphere, giving rise to a sulphate loading of $30 \mathrm{Mt}$, about two orders of magnitude more than during volcanically quiescent periods (McCormick et al., 1995). The particles were dispersed globally during a year or more after which they were transported back into the troposphere where they are deposited to the surface on a timescale of about a week. Studies of the Mt. Pinatubo eruption have provided much insight into the climate cooling influence of stratospheric sulphur (see e.g. Robock, 2000) and also about the 
performance of our model (see Sect. 3 and poster presented at the EGU Assembly 2011, http://presentations.copernicus. org/EGU2011-6463_presentation.ppt). Although strong volcanic eruptions can dominate stratospheric particles for several years, in volcanically quiescent periods a much thinner aerosol layer persists, as discovered by Junge et al. (1961). Crutzen (1976) proposed that the conversion of COS into sulphuric acid may contribute significantly to the non-volcanic stratospheric aerosol. On a global scale COS is the most abundant sulphur gas in the atmosphere (Bandy et al., 1992; Mihalopoulos et al., 1991; Montzka et al., 2007; Barkley et al., 2008). Because COS is relatively inert in the troposphere it can be transported into the stratosphere where it is broken down by photodissociation through the absorption of ultraviolet sunlight (Turco et al., 1980; Crutzen, 1976). As a rather long-lived trace gas its distribution is modulated by the QBO in the tropical upwelling region. Theatmosphere contains many reduced and partly oxidised sulphur gases, the most important being $\mathrm{SO}_{2}$, hydrogen sulphide $\left(\mathrm{H}_{2} \mathrm{~S}\right)$, dimethyl sulphide (DMS), COS and $\mathrm{CS}_{2}$. Most have significant anthropogenic sources, in particular $\mathrm{SO}_{2}$, which is released in large quantities from the combustion of coal. The ultimate reaction product of all sulphur species is sulphuric acid, which has a low volatility and largely condenses into sulphate particles, except for the upper stratosphere and the mesosphere, where the most abundant sulphur species is $\mathrm{SO}_{2}$ (e.g. Rinsland et al., 1995).

In the next section we present a brief overview of available information about atmospheric COS, including sources, the chemical behaviour and atmospheric lifetime, while we refer to the more comprehensive review by SPARC (2006) for details. In the subsequent sections we present calculations with our chemistry-climate model EMAC of stratospheric aerosol and its forcings, and compute the global warming potential of COS. We conclude by assessing the role of COS in the stratospheric sulphur budget and the overall climate effects from anthropogenic emissions, including the chemically induced indirect effects through stratospheric aerosol.

\section{Atmospheric budgets}

Sulphur is an essential trace element for life on Earth, and its availability in the natural environment is usually not ratelimiting for the growth of organisms. One reason is that sulphur is plentiful in seawater. Sulphate is the third most abundant compound in sea salt with a dry mass fraction of about $7.7 \%$. Moreover, seawater is usually supersaturated with sulphur containing gases such as DMS. Also in natural terrestrial ecosystems, for example tropical rainforests, sulphur is usually not growth limiting owing to the atmospheric transport from the marine environment. It seems likely that COS may actually play a key role in "nourishing" the natural terrestrial biosphere with sulphur, considering that there is a strong correlation between COS uptake by the vegetation and $\mathrm{CO}_{2}$ assimilation (Sandoval-Soto et al., 2005).

Biological processes produce a range of reduced-sulphur gases (Andreae, 1990). The six most important are $\mathrm{H}_{2} \mathrm{~S}$, $\mathrm{CS}_{2}, \mathrm{COS}, \mathrm{CH}_{3} \mathrm{SH}$ (methyl mercaptan), $\mathrm{CH}_{3} \mathrm{SCH}_{3}$ (DMS) and DMDS (dimethyl disulphide). Saline ecosystems such as salt marshes and estuaries are particularly strong sources. The supersaturation of sulphur gases in the aqueous phase relative to the overlying air is largely caused by the microbial degradation of organic matter.

Carbon disulphide is not very soluble and seawater is generally supersaturated, so that the oceans are a $\mathrm{CS}_{2}$ source to the atmosphere. Unfortunately, in situ observations both in the atmosphere and the upper ocean are scarce (e.g. Blake et al., 2004). Since ocean-atmosphere fluxes are calculated with models that use the measured concentrations in seawater, the source estimates are rather uncertain. Although oceans and coastal regions represent the major source of $\mathrm{CS}_{2}$, anoxic soils and wetlands can also release significant quantities. According to Watts (2000) and Chin and Davis (1993) the largest anthropogenic contribution comes from the chemical industry, notably fiber production.

The data availability for COS is somewhat better, but also for this gas the source estimates are associated with substantial uncertainty. The emission categories of COS much resemble those of $\mathrm{CS}_{2}$ although several additional sources need to be accounted for. For example, it has been observed that rainwater is supersaturated with COS so that outgassing may be significant. The analysis of rain and snow samples has shown that COS is produced photochemically in precipitation (Mu et al., 2004). Further, the burning of biomass releases COS, as observed in the exhaust plumes from boreal and savannah fires (Crutzen et al., 1979). Note that biomass burning is mostly anthropogenic and only a small fraction of the fires is ignited naturally by lightning (J. Goldammer, personal communication, 2011).

The oceans near the surface are generally COS supersaturated and thus release the gas to the atmosphere, mostly as a function of the temperature-dependent hydrolysis in seawater (Kettle et al., 2002). The flux of COS is therefore highest in high latitudes during summer, whereas in low latitudes the upper ocean can be undersaturated and act as a small sink. The atmospheric oxidation of reduced sulphur gases, in particular DMS and $\mathrm{CS}_{2}$, also produces COS. Since oceans are an important source of DMS, they are also an indirect source of COS.

By considering the total sulphur source to the atmosphere it becomes evident that in the era of fossil fuel use and industrialization the anthropogenic emission of $\mathrm{SO}_{2}$ has become a dominant factor in the atmospheric sulphur cycle (Lelieveld et al., 1997). The analysis of an Antarctic ice core has provided evidence that COS has also increased due to anthropogenic activity (Montzka et al., 2004). Although atmospheric COS has been rather constant at $450-500$ pptv in the past century, its mixing ratio has substantially increased 
Table 1. Global atmospheric budget of COS after Watts (2000).

\begin{tabular}{ll}
\hline Sources & $\begin{array}{l}\text { Annual flux } \\
\left(\mathrm{Mt} \mathrm{yr}^{-1}\right)\end{array}$ \\
\hline Open ocean & $0.10 \pm 0.15$ \\
Coastal ocean (incl. salt marshes, estuaries) & $0.20 \pm 0.10$ \\
Anoxic soils & $0.02 \pm 0.01$ \\
Wetlands & $0.03 \pm 0.03$ \\
Volcanism & $0.05 \pm 0.04$ \\
Precipitation & $0.13 \pm 0.08$ \\
DMS oxidation & $0.17 \pm 0.04$ \\
CS oxidation (50\% anthropogenic) & $0.42 \pm 0.12$ \\
Biomass burning & $0.07 \pm 0.05$ \\
Anthropogenic (direct) & $0.12 \pm 0.06$ \\
Total source & $1.31 \pm 0.25$ \\
\hline Sinks & \\
\hline Oxic soils & $0.92 \pm 0.78$ \\
Vegetation & $0.56 \pm 0.10$ \\
Reaction with OH & $0.13 \pm 0.10$ \\
(this work) & $0.245 \pm 0.035$ \\
Reaction with O & $0.02 \pm 0.01$ \\
(this work) & $0.016 \pm 0.001$ \\
Photodissociation & $0.03 \pm 0.01$ \\
(this work) & $0.047 \pm 0.006$ \\
Total sink & $1.66 \pm 0.79$ \\
(this work) & $1.79 \pm 0.79$ \\
\hline Total imbalance & $0.35 \pm 0.83$ \\
(this work) & $0.48 \pm 0.83$ \\
\hline & \\
\hline
\end{tabular}

by about $35-40 \%$ from approximately $350 \mathrm{pptv}$ or less since pre-industrial times (Sturges et al., 2001; Montzka et al., 2004; Aydin et al., 2008).

The global atmospheric COS budget has been estimated in Table 1, after Watts (2000). The budget is not balanced though well within the uncertainty ranges, as also concluded by Kettle et al. (2002). Notholt et al. (2003) suggested that tropical biomass burning is a larger COS source than assumed previously, but even if it would be a factor of three larger than in Table 1 the budget implications would be minor. However, a substantially larger source from the atmospheric oxidation of $\mathrm{CS}_{2}$, for example from coal-fired furnaces in China and elsewhere, would have important consequences.

COS has a chemical lifetime of about $35 \mathrm{yr}$, and is governed by reactions with $\mathrm{OH}, \mathrm{O}$ and photodissociation. Oxidation by $\mathrm{OH}$ contributes to the seasonal cycle of $\mathrm{COS}$ in the troposphere with a peak in spring and a minimum in fall. Furthermore, the removal of COS from the atmosphere is strongly augmented through the consumption by the terrestrial biosphere. Plants can take up COS through the stomata and assimilate it even more efficiently than $\mathrm{CO}_{2}$ (SandovalSoto et al., 2005). In addition, it has been observed that especially during the night, when the plant stomata are closed, oxic soils can be an important sink for atmospheric COS (Kuhn et al., 1999; Steinbacher et al., 2004). The biological processes involved are dependent on temperature and humidity, which gives rise to strong diurnal and seasonal cycles, especially in middle and high latitudes (Kettle et al., 2002). Since the number of measurements is limited, it is difficult to estimate the sink strengths, especially of soils (Van Diest and Kesselmeier, 2008).

Sandoval-Soto et al. (2005) have re-assessed the global COS uptake by terrestrial vegetation. They find that the rate of COS removal from the atmosphere is significantly larger than of $\mathrm{CO}_{2}$. By scaling with net primary productivity data they estimate a global COS sink of $0.69-1.40 \mathrm{Mt} \mathrm{yr}^{-1}$. Furthermore, since a COS molecule is irreversibly split within the plant tissue, in contrast to $\mathrm{CO}_{2}$ which can be released again by respiration, the gross rather than the net primary productivity must be accounted for. The thus corrected sink term is much larger, $1.4-2.8 \mathrm{Mt} \mathrm{yr}^{-1}$. A recent model analysis of aircraft measurements of COS over the United Stated has provided further evidence of a strong photosynthetic sink (Campbell et al., 2008). By invoking the latter estimate into Table 1 the budget deficit increases by more than a factor of five, much beyond the uncertainty range given by Watts (2000). However, the budget could be brought into better balance again by assuming a much larger COS source from $\mathrm{CS}_{2}$ oxidation as associated with coal-fired furnaces. Although these considerations will remain speculative until improved datasets become available, there are indications that both the source and sink terms of COS are substantially underestimated.

Due to its relatively long total effective lifetime of more than two years (i.e. much longer than other S-compounds), some COS survives the slow transport from the tropical troposphere into the stratosphere where it is converted by photodissociation and reaction with $\mathrm{O}$-atoms into $\mathrm{SO}_{2}$. The latter is oxidised by $\mathrm{OH}$ via $\mathrm{SO}_{3}$ (Sander et al., 2006) into gaseous sulphuric acid, which binds water vapour and forms acidic aerosol particles, dependent on temperature and humidity. In the upper stratosphere sulphuric acid is present in the gas phase since sulphate aerosols evaporate at the relatively high temperature and the low pressure. Its photolysis by visible and UV radiation (Vaida et al., 2003; Hintze et al., 2003; Mills, 2005) causes the mixing ratio of $\mathrm{SO}_{2}$ to increase with altitude (Rinsland et al., 1995).

\section{Chemistry-climate model results}

To calculate the global transport fluxes and atmospheric chemistry-climate interactions we make use of computer simulations with the ECHAM5 general circulation model (Roeckner et al., 2006), coupled to the Modular Earth Submodel System (MESSy, Jöckel et al., 2006) Atmospheric Chemistry (EMAC) model. The coupled EMAC model together with the aerosol module GMXe (Pringle et al., 2010) 
Table 2. Parameters of the aerosol size distribution in GMXe. Nucleation mode only for soluble particles.

\begin{tabular}{lrrrr}
\hline Mode & Nucleation & Aitken & Accumulation & Coarse \\
\hline$r_{\min }, \mu \mathrm{m}$ & 0.0005 & 0.006 & 0.07 & 1 \\
$\sigma$ & 1.59 & 1.59 & 1.49 & 1.7 \\
\hline
\end{tabular}

and the chemistry module MECCA (Sander et al., 2005) includes a comprehensive account of tropospheric and stratospheric dynamical, cloud, radiation, multiphase chemistry, emission and deposition processes. The aerosol module GMXe has 4 size modes for soluble and 3 for unsoluble aerosols with lognormal size distributions. Compared to Pringle et al. (2010) the mode boundaries were adjusted to larger sizes and the sigma values were reduced to accomodate both stratospheric and tropospheric aerosol, see Table 2. In the module we allow for nucleation, coagulation and evaporation using the sulphuric acid vapor pressure approximation by Vehkamäki et al. (2002). It includes also shrinking of particles, i.e. transfer to smaller modes due to evaporation. Accumulation and coarse mode particles are slowly transported to the troposphere by sedimentation using a modified Walcek scheme (Benduhn, in preparation) with negligible numerical diffusion. The model also considers downward transport of sulphate by sedimentating solid polar stratospheric cloud particles. Lower boundary conditions for the different aerosol types are as described in Pringle et al. (2010). Aerosol extinction is calculated from Mie theory using pre-calculated look-up tables for the 6 aerosol components water, water soluble species, organic carbon, black carbon, dust and sea salt. The radiation module can perform additional diagnostic calculations of radiative forcing for different aerosol options. In this study the GMXe-calculated aerosol does not feed back to the model dynamics which would affect the climate. Scavenging of soluble gases and aerosol particles by droplets and ice is included. The ice phase scavenging rates by impaction and nucleation are dependent on temperature, precipitation flux and cloud cover.

We apply the model at T42 resolution, i.e. about $2.8^{\circ}$ in latitude and longitude. The vertical grid structure resolves the lower and middle atmosphere with 90 layers from the surface to a top layer centred at $0.01 \mathrm{hPa}$ (Giorgetta et al., 2006). This model configuration was selected because it explicitly represents stratosphere-troposphere interactions and has been extensively tested and documented (Lelieveld et al., 2007; Jöckel et al., 2006). The configuration is also able to generate a self-consistent quasi-biennial oscillation in the tropical stratosphere.

The period January 1999 to September 2002 was selected to allow for comparison with SAGE satellite observations during a period when volcanic eruptions had only minor influence, i.e. close to "background" stratospheric conditions. The model was initialized in January 1996 using observed
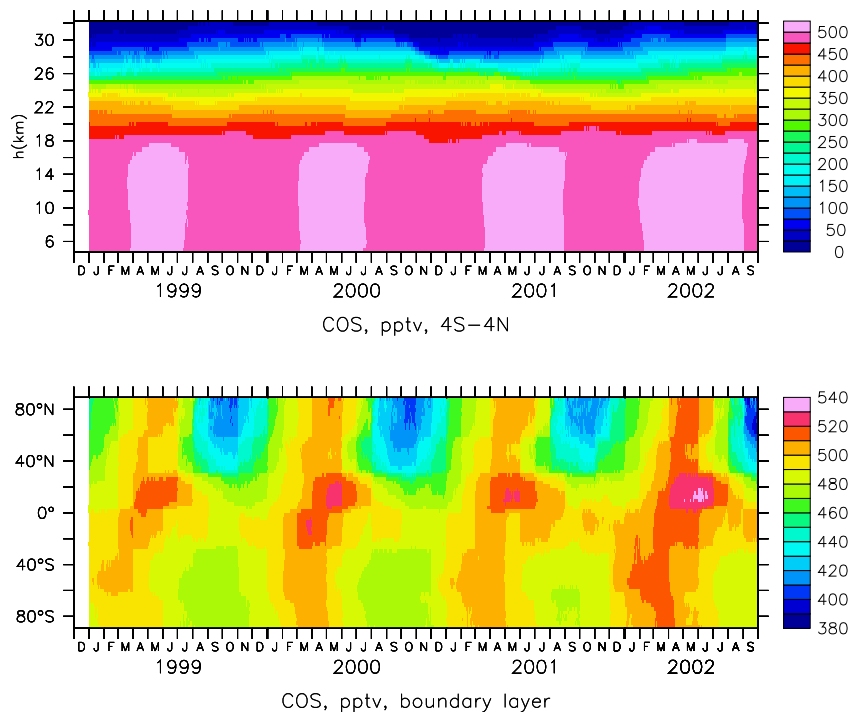

Fig. 1. Time series of COS mixing ratios (in pptv) simulated by EMAC. Upper panel: tropics, colors and altitude range as in Barkley et al. (2008). Lower panel: boundary layer.

meteorology and distributions of long-lived chemical species including COS from the Mainz chemical 2D-model (Grooß et al., 1998; Andersen et al., 2006). The first $3 \mathrm{yr}$ are considered as spinup. As in Jöckel et al. (2006), the phases of the QBO stay close to observations for at least the first 7 years so that direct comparisons of chemical species distributions with satellite data are possible.

Considering that the source and sink terms of COS are rather uncertain, we apply measurements from a global network as surface boundary conditions in the model. Since the year 2000 the National Oceanic and Atmospheric Administration (NOAA) has monitored COS in a global flask sampling programme based on 12 measurement stations, mostly located in background locations on islands and remote continental sites (Montzka et al., 2007). The flasks are filled when the wind is from a pre-defined clean air sector to prevent influences by local pollution sources.

The measurements and consequently our model results (Fig. 1, lower panel) show that the mean mixing ratio in the Northern Hemisphere, 470-480 pptv, is slightly lower than in the Southern Hemisphere, 490 pptv, with little interannual variability. Note that some analyses indicated a slow decrease of atmospheric COS since the 1980s (Sturges et al., 2001; Rinsland et al., 2002), whereas recent data show a slight upward trend (Montzka et al. (2007), and more recent data on the corresponding website). The slight decrease followed by an increase is also seen in Space Shuttle and satellite data of the subtropical lower stratosphere (Rinsland et al., 2008). The annual mean COS mixing ratios in background locations typically vary within $0.48 \pm 0.04 \mathrm{ppbv}$. The highest mean values occur in low latitudes. At middle and low latitudes in the Southern Hemisphere the mixing ratios 

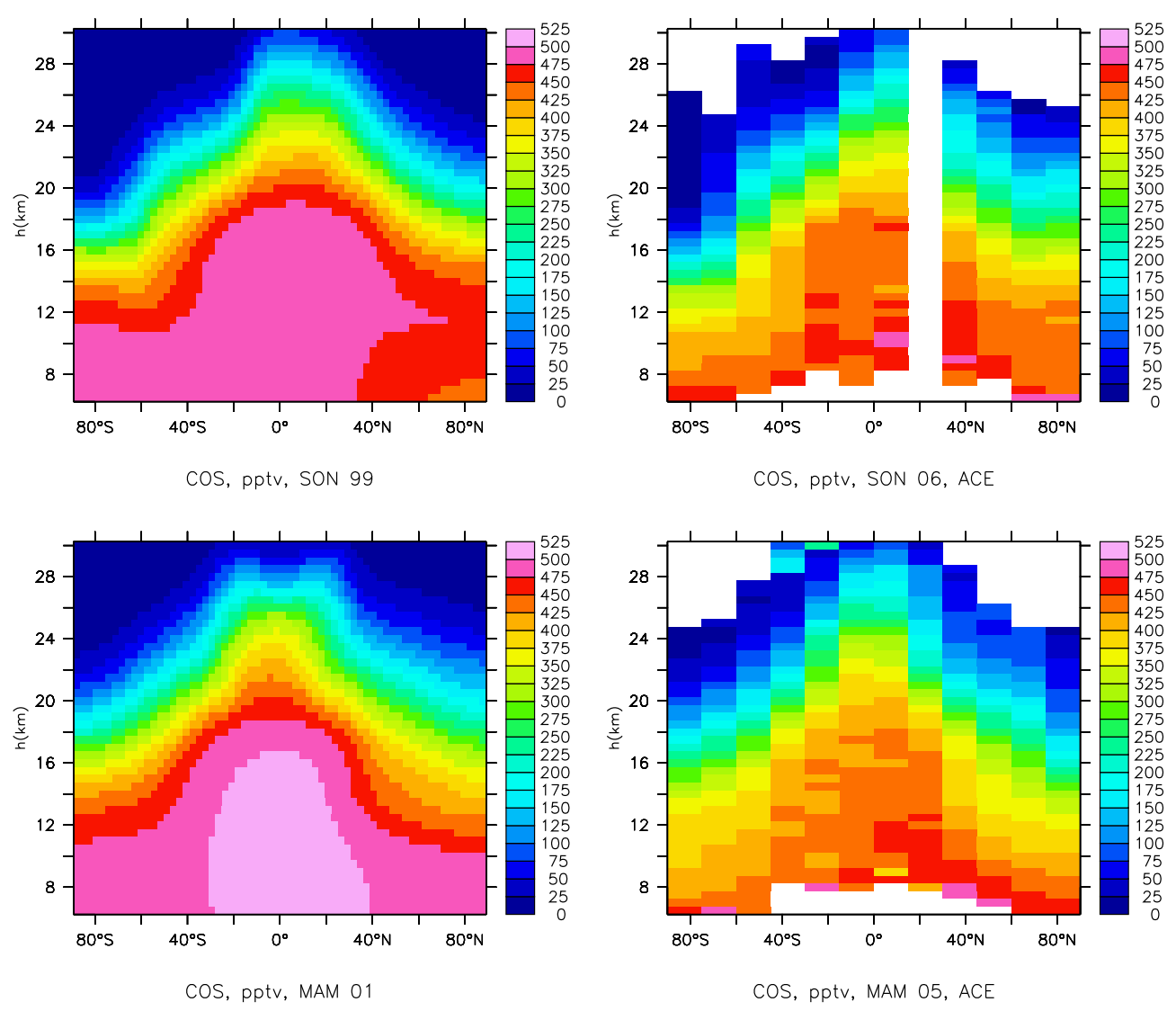

Fig. 2. Simulated zonal mean COS mixing ratios (in pptv) for September to November 1999 and March to May 2001 (left). ACE observations for SON 2006 and MAM 2005 (taken from Barkley et al. (2008), data of their Fig. 3, right).

are slightly lower, whereas the lowest mean levels occur in the Northern Hemisphere in fall.

Our model calculates an air mass flux across the tropical tropopause (at $100 \mathrm{hPa}, 20^{\circ} \mathrm{S}$ to $20^{\circ} \mathrm{N}$ ) of $2.78 \times 10^{8} \mathrm{Mt} \mathrm{yr}^{-1}$. Based on a mean COS mixing ratio of $0.48 \mathrm{ppbv}$ at this altitude (Fig. 1, upper panel and Fig. 2) this translates into a mass flux into the stratosphere of about $0.15 \mathrm{MtS} \mathrm{yr}^{-1}$, comparable to previous estimates of the total sulphur flux (SPARC, 2006). The model results demonstrate that during boreal winter the upward transport predominantly occurs south of the equator, to a large extent over the western Pacific. In summer upward fluxes are also rather strong over the western Pacific north of the equator and over the Asian monsoon. If Southeast Asia would be a significant source of $\mathrm{CS}_{2}$ and $\mathrm{COS}$, as indicated by the measurements of Blake et al. (2004), this could directly impact the COS flux into the stratosphere through rapid upward transport in the monsoon season. Notholt et al. (2003) measured enhanced COS concentrations in the tropical upper troposphere, which they attributed to tropical biomass burning. Direct and seasonal COS measurements over the South Asian monsoon, where the upward fluxes reach a maximum, and at the tropical tropopause in other locations would provide the information needed to establish if enhanced COS affects the stratosphere and thus help test our model results. COS is most abundant in the tropics and has a significant seasonal variability, being most pronounced in the Horthern Hemisphere.

Consistent with observations, the model results show relatively high COS mixing ratios in the tropics at the surface which extend up to about $16 \mathrm{~km}$ altitude near the tropopause. Notholt et al. (2003) observed COS mixing ratios in excess of $0.5 \mathrm{ppbv}$ between 8 and $16 \mathrm{~km}$ altitude, though their measurements were limited to the Atlantic Ocean and to relatively short periods during and after the biomass burning season. If the measurements of Notholt et al. (2003) would be representative for the entire year and globe, we would underestimate $\mathrm{COS}$ at the tropical tropopause and its transport into the stratosphere by about $20-25 \%$. However, the evidence for an upper tropospheric COS maximum is mixed, only partly corroborated by Space Shuttle measurements in the 1990s (SPARC, 2006). Moreover, measurements over the Pacific Ocean at $10-12 \mathrm{~km}$ altitude give no evidence of enhanced COS (Blake et al., 2004).

Recent satellite observations by ACE-FTS show up to about $0.45 \mathrm{ppbv}$ COS near the tropopause (Barkley et al., 2008), slightly lower than indicated by our model 

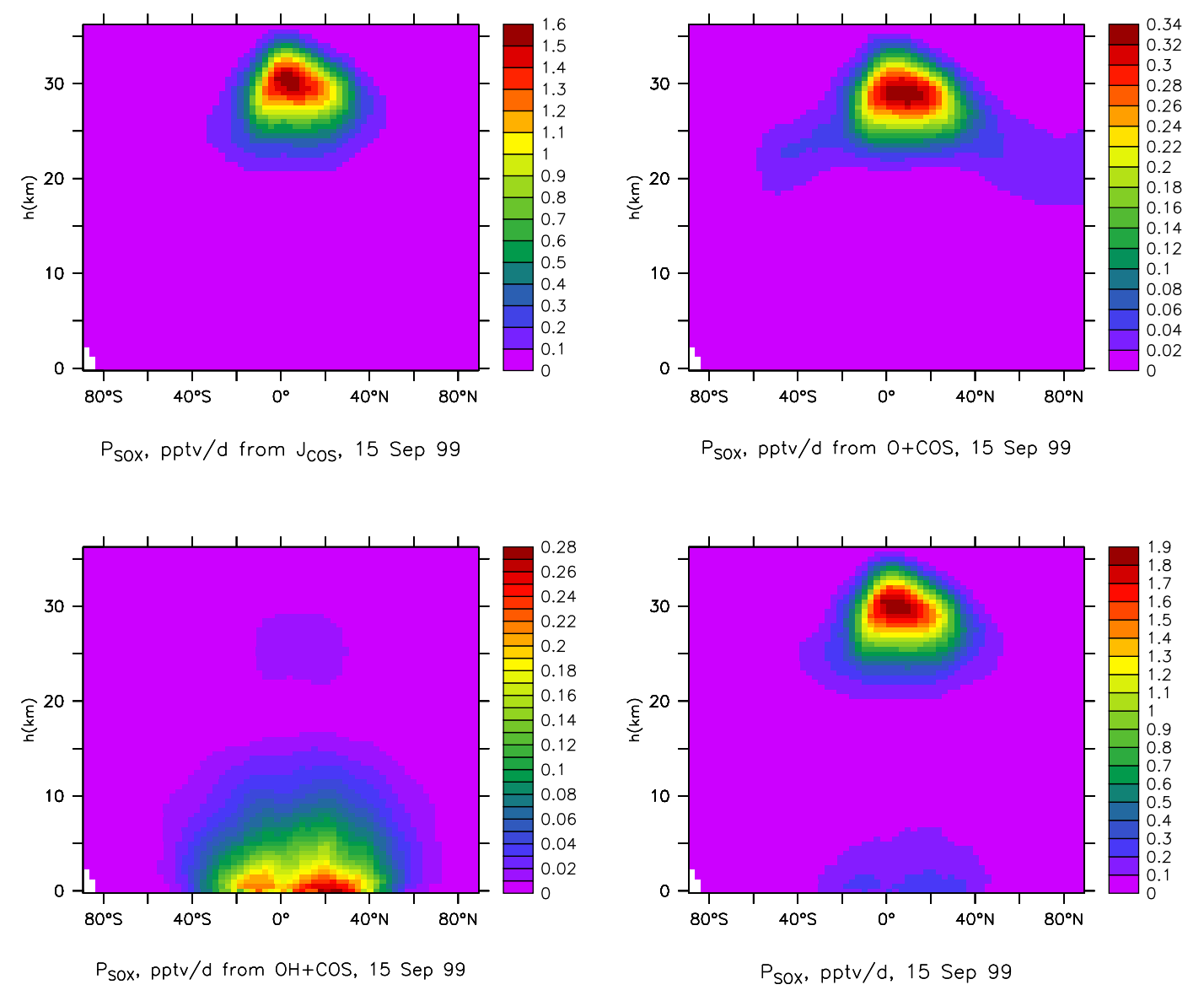

Fig. 3. $\mathrm{SO}_{\mathrm{x}}$ production from COS, pptv day ${ }^{-1}$, September $1999\left(\mathrm{SO}_{\mathrm{x}}=\mathrm{SO}_{2}+\mathrm{SO}_{3}+\mathrm{SO}+\mathrm{SH}+\mathrm{S}\right)$. Upper left: photolysis, upper right: reaction with $\mathrm{O}\left({ }^{3} \mathrm{P}\right)$, lower left: reaction with $\mathrm{OH}$, lower right: total.

simulations (Fig. 2) based on the observed surface concentrations. The model reproduces the modulation by the QBO leading to interannual variability of the the stratospheric sulphur source as shown in the two examples for the different QBO phases and seasons discussed later. Unfortunately, for the selected years no satellite observations are available but for the long-lived COS with only small longterm trends it should be appropriate to compare with the later years shown in Barkley et al. (2008) for similar QBO-phases and seasons. The simulated COS mixing ratios appear to be 5 to $10 \%$ high compared to the ACE-observations of Barkley et al. (2008), though comparisons with balloon observations indicate that a low bias of the satellite data in the same range cannot be excluded.

Figure 3 shows the production rates of inorganic sulphur from COS, indicating that photolysis is dominating. The integrated photochemical sink as calculated by EMAC is $0.3 \mathrm{Mt} \mathrm{yr}^{-1}$ which corresponds to the upper limit of Watts (2000) in Table 1. Their value, however, is based on a rather simple model estimate. In the stratosphere (above $100 \mathrm{hPa}$ ) about $0.065 \mathrm{Mt} \mathrm{yr}^{-1}$ of COS is converted to aerosol. In the absense of sinks it would take about 1 to $2 \mathrm{yr}$ to reach the observed sulphate concentrations. In our simulations where stratospheric mixing ratios of $\mathrm{SO}_{2}$, gaseous $\mathrm{H}_{2} \mathrm{SO}_{4}$ and sulphate aerosol were initialized from zero and the ones of COS with about the observed distributions (January 1996), most of the stratospheric aerosol layer forms in the first year. It takes about 3 simulated years to reproduce also the gaseous inorganic sulphur species in the middle and upper stratosphere close to observations due to the long transport times.

In Fig. 4 it is illustrated that the sharp vertical gradient of $\mathrm{COS}$ in the stratosphere coincides with a sharp increase of particulate sulphuric acid with altitude (cf. Fig. 2). The right panel, for another season and QBO phase, shows large differences in the distribution of sulphate compared to the left panel in the tropics but again good agreement of the patterns with observations. Sulphate from COS appears to account for about 65 to $75 \%$ of the observed aerosol as derived from SAGE observations (e.g. Thomason et al., 1997). In the lower stratosphere organic carbon aerosol from biomass burning (emission see Pringle et al., 2010) appears to contribute significantly to aerosol surface area density and mixing ratios. Figure 5 shows the temporal evolution of simulated sulphate aerosol in the tropics after 3 years of spinup, 

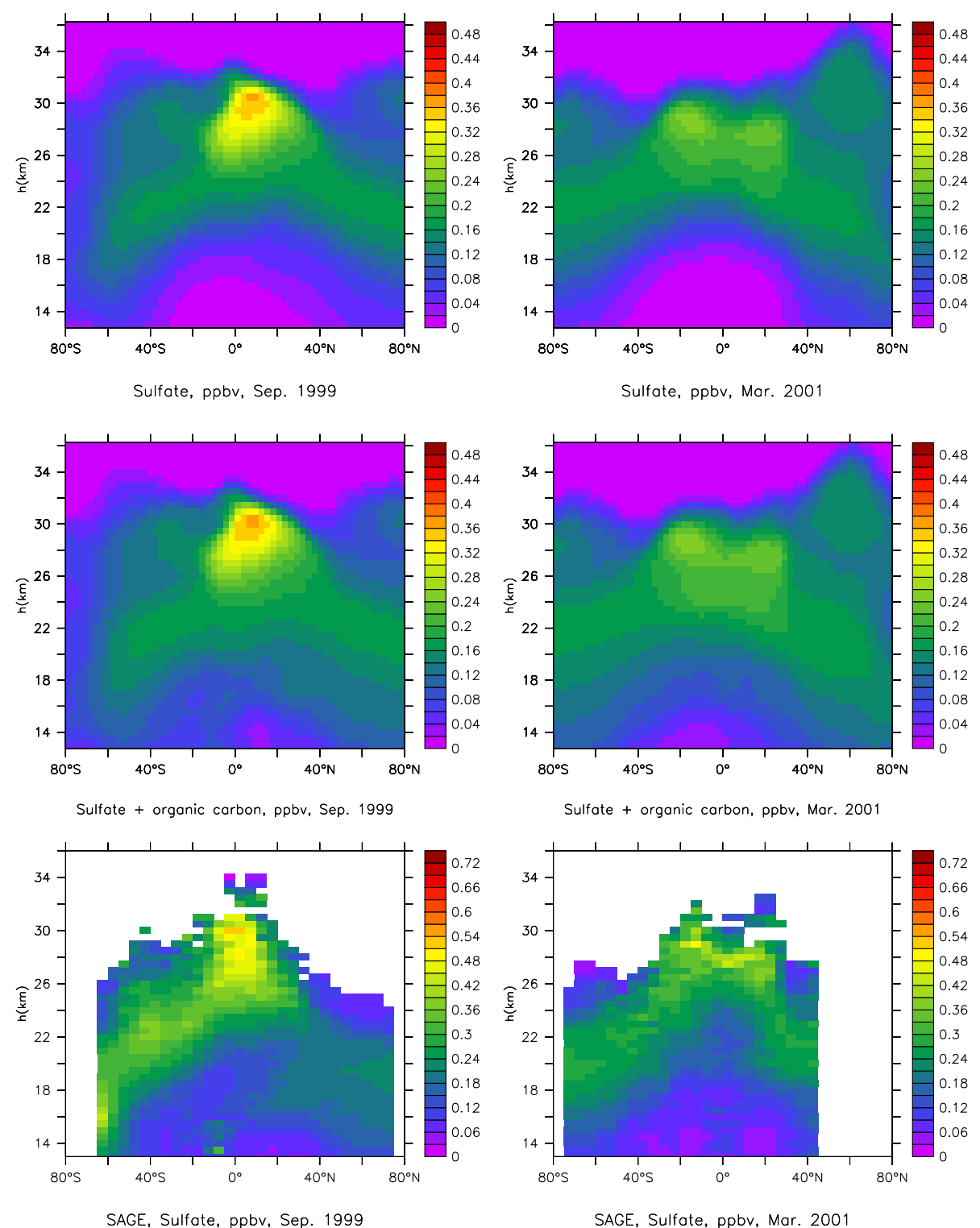

Sulfote + organic carbon, ppbv, Mar. 2001

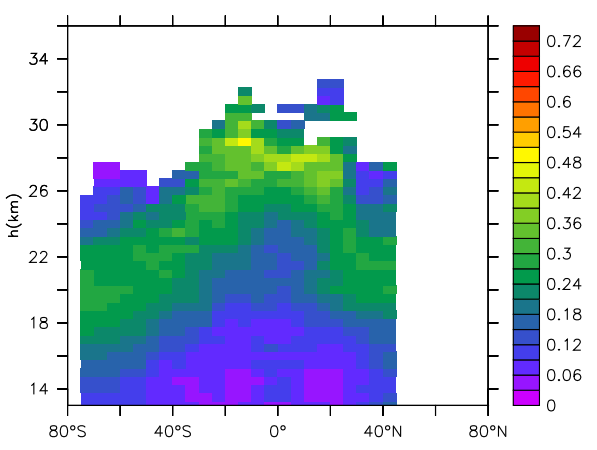

SAGE, Sulfate, ppbv, Mar. 2001

Fig. 4. Simulated (upper panels) and observed (lower panels, derived from SAGE) sulphate aerosol in September 1999 (left) and March 2001 (right), ppbv. The middle panels includes simulated organic carbon aerosol (mostly from biomass burning, mass weighted). Note that the color scale of the model covers only $67 \%$ of the range of the one for the observations to account for the model's low bias and to allow for more convenient comparisons of patterns.

modulated by the QBO (black contours show zonal wind) together with aerosol mixing ratios derived from SAGE data (without extrapolations for data gaps) using the empirical formula by Grainger et al. (1995) to convert aerosol surface area density into sulphate mixing ratios. Our model results, which yield a maximum sulphate mixing ratio of $0.35 \mathrm{ppb}$ in the tropics, are consistent with the satellite measurements (SAGE), including the modulation by the QBO. Simulated sulphate aerosol from COS explains on average $70 \%$ of the observed stratospheric aerosol burden of $45 \mathrm{kt} S$ above $20 \mathrm{~km}$ (see Supplement).
The model results indicate that dust and especially organic carbon aerosol also contribute to the aerosol in the lowermost stratosphere as also mentioned in the SAGE evaluation by Thomason et al. (2008) and in the compilation of in situ observations by Murphy et al. (2007). Including organic carbon reproduces most of the seasonal patterns observed by SAGE in the lower stratosphere (Fig. 5). This holds also for the aerosol burden above $16 \mathrm{~km}$ (or $100 \mathrm{hPa}$ ) where simulated sulphate is 40 to $50 \mathrm{kt} \mathrm{S}$ and organics about 10 to $15 \mathrm{kt}$, compared to about $80 \mathrm{kt}$ (total as S) derived from SAGE (see Supplement). Note that aerosol water, which contributes 

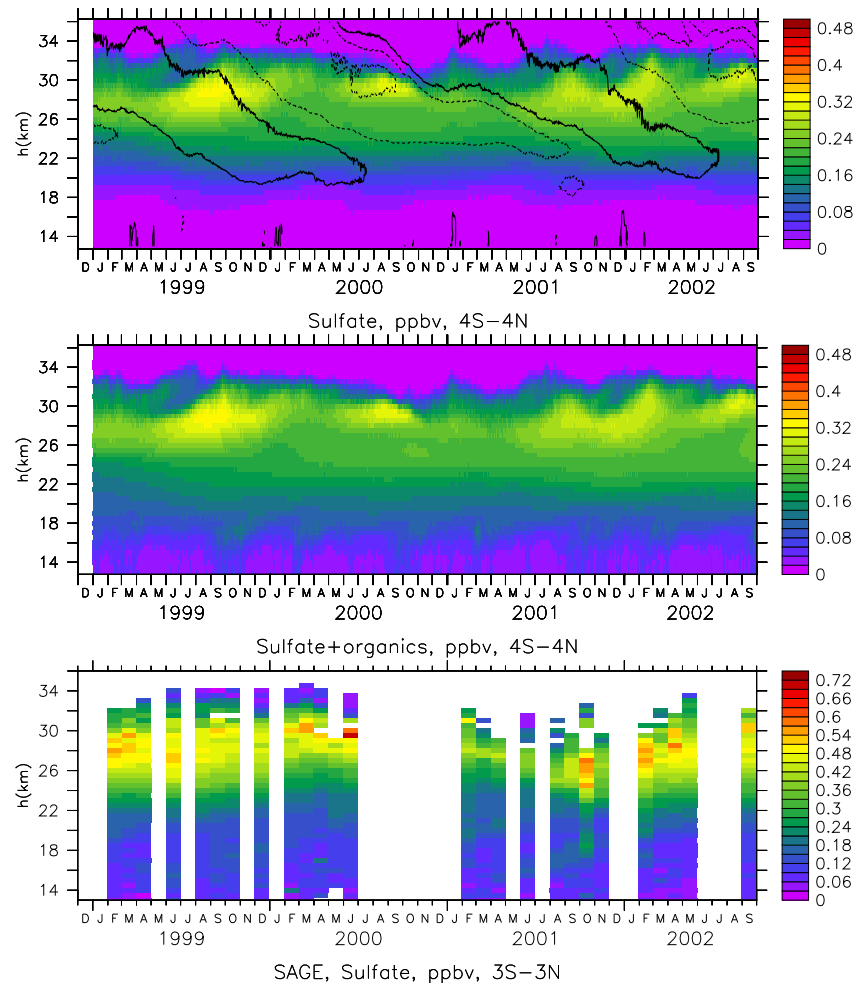

Fig. 5. Simulated (upper panel) and SAGE satellite derived (lower panel) sulphate aerosol in the tropics, ppbv. Black contours give the zonal wind (QBO), in steps of $20 \mathrm{~m} \mathrm{~s}^{-1}$, beginning with $-30 \mathrm{~m} \mathrm{~s}^{-1}$ (dotted contours negative or easterlies). The middle panel includes simulated organic carbon aerosol. Range of color scales as in Fig. 4

about 15 to $30 \%$ to the observed mass (G. Yue, NASA Langley, personal communication at AGU meeting 2011) introduces uncertainties in the conversion formula from extinction to sulphate volume mixing ratio. EMAC-results for a wider latitude range and for mode radii and number concentrations are given in the Supplement.

As shown in Fig. 6, above about $10 \mathrm{hPa}$ (about $30 \mathrm{~km}$ ) or a temperature of $233 \mathrm{~K}$ most of the simulated sulphur is in the gas phase. In the middle stratosphere $\mathrm{H}_{2} \mathrm{SO}_{4}$ vapor is most abundant. Near the stratopause (and higher up) $\mathrm{SO}_{2}$ is the dominating species with about $0.1 \mathrm{ppbv}$ as observed by ATMOS (Rinsland et al., 1995). Near the tropical tropopause $\mathrm{SO}_{2}$ is close to absent due to oxidation and scavenging by sedimenting ice particles. At about $30 \mathrm{~km} \mathrm{SO}_{2}$ shows a small secondary maximum related to its production from COS photolysis (see Fig. 3).

The calculated total aerosol extinction at $1000 \mathrm{~nm}$ in Fig. 7 also agrees well and is consistent (i.e. low by about 30-40\%) with observations of SAGE (SPARC, 2006). This holds also for extinction at $530 \mathrm{~nm}$ (not shown). The largest underestimates of about $50 \%$ occur around $23 \mathrm{~km}$ altitude in the tropics. The dominating contributions to total extinction
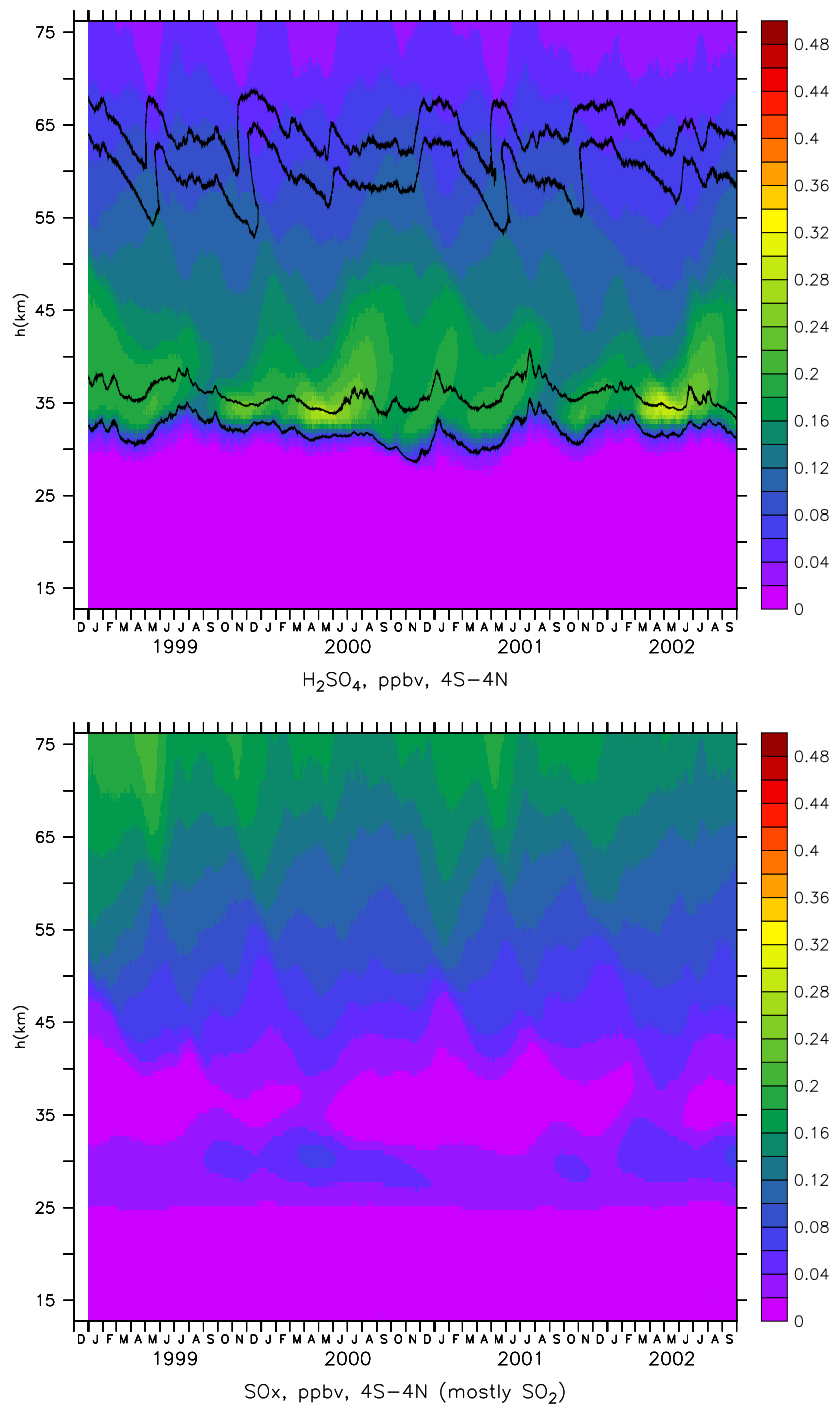

Fig. 6. Simulated gaseous $\mathrm{H}_{2} \mathrm{SO}_{4}$ and $\mathrm{SO}_{\mathrm{x}}$ (mostly $\mathrm{SO}_{2}$ ) in the tropics, ppbv. The contours in the upper panel show mean temperatures of 230 and $240 \mathrm{~K}$, the region where sulphate aerosol evaporates.

are sulphate, aerosol water and organic carbon as shown in Fig. 8. Dust contributes in the upper northern tropical troposphere. The calculated extinction at $2450 \mathrm{~nm}$ is also consistently about $35 \%$ low compared to HALOE in the Junge layer if the refractive indices of sulphuric acid as in Hervig et al. (1996) are used in the Mie lookup tables (using ammonium sulphate for water soluble aerosol here leads to an underestimate of more than $60 \%$ ). Figure 7 furthermore suggests that our model underestimates aerosol extinction in the upper stratosphere. It is conceivable that an assumed flux of meteoric dust of about $0.01-0.02 \mathrm{Mt} \mathrm{yr}^{-1}$ (SPARC, 2006) would compensate this "missing" aerosol source in the upper stratosphere and by about half in the lower and middle stratosphere. 

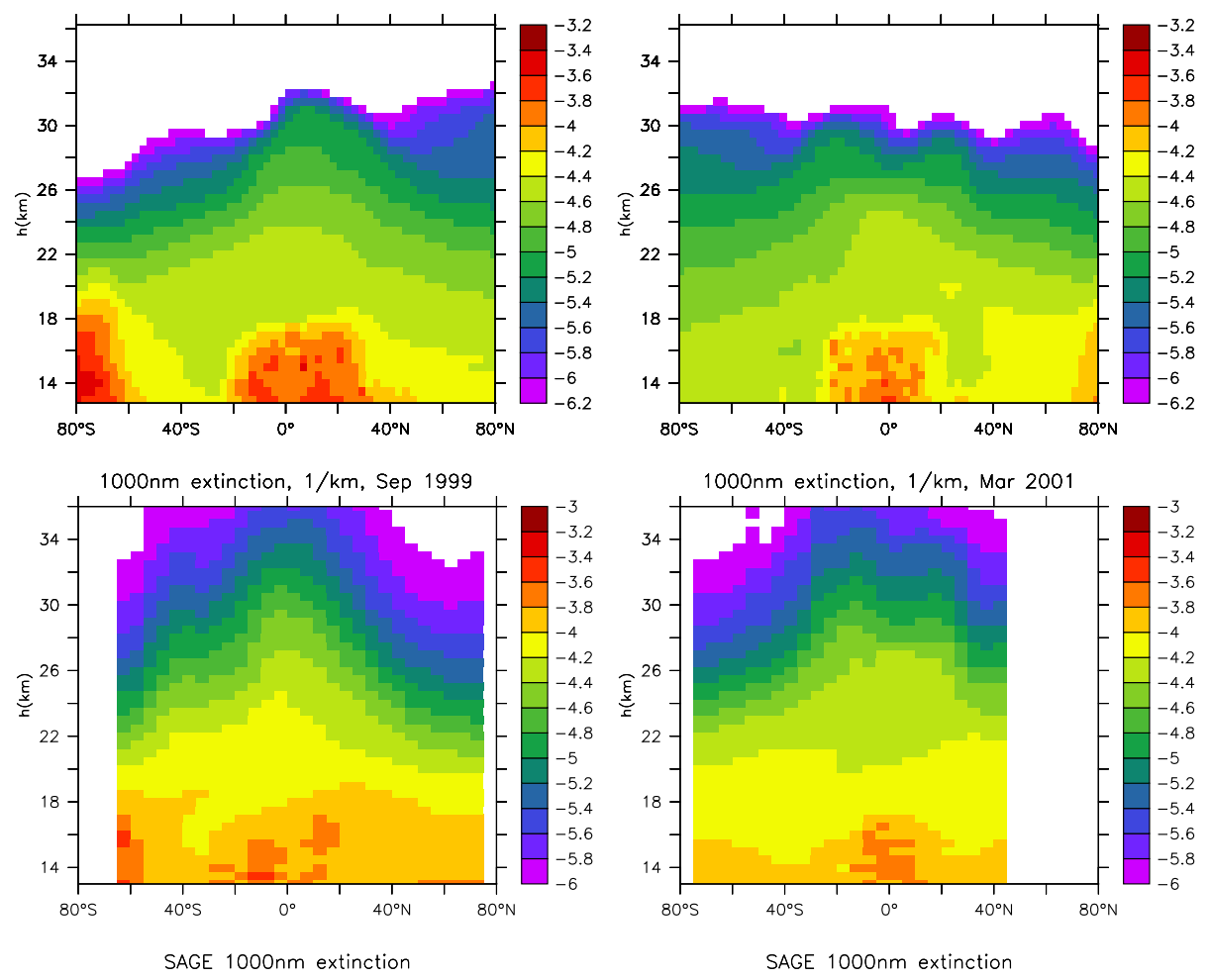

Fig. 7. Simulated (upper panels) and observed (lower panels) aerosol extinctions at $1000 \mathrm{~nm}$ (decadal logarithm) for September 1999 (left) and March 2001 (right). Color scale for model shifted by one step to account for low bias (65\%, Fig. 4).

In the model of Weisenstein et al. (1997), which was also used by SPARC (2006), $\mathrm{SO}_{2}$ mixing ratios of $40-50 \mathrm{ppt}$ were prescribed in air transported into the stratosphere. Furthermore additional small fluxes of other short-lived gases such as $\mathrm{CS}_{2}$ and $\mathrm{H}_{2} \mathrm{~S}$ were included. This seems at odds with measured $\mathrm{SO}_{2}$ mixing ratios in the background upper troposphere, which are generally below 10-20 ppt (Thornton et al., 1999). In fact, upward transport through the tropical tropopause layer (12-18 km altitude) is very slow and the air mass residence time is several months. The chemical lifetime of $\mathrm{SO}_{2}$ through reaction with $\mathrm{OH}$ in the tropical tropopause layer is about two weeks and that of $\mathrm{CS}_{2}, \mathrm{H}_{2} \mathrm{~S}$ and DMS only a few days. Therefore it seems unlikely that short-lived sulphur gases could survive oxidation into $\mathrm{H}_{2} \mathrm{SO}_{4}$ and be transported into the stratosphere. Furthermore, $\mathrm{H}_{2} \mathrm{SO}_{4}$ has a low volatility and quickly deposits onto the surfaces of ice crystals, ubiquitously present in the tropical tropopause layer. Since less than $1 \%$ of the water that enters the tropopause layer at $12 \mathrm{~km}$ actually reaches the stratosphere at $18 \mathrm{~km}$, associated with the "freeze-drying" of the cold tropopause, most water is removed by the sedimentation of ice particles, which also prevents sulphuric acid to reach the stratosphere (due to scavenging). Our results are thus consistent with the hypothesis of Crutzen (1976) and Turco et al. (1980) that at least about $70 \%$ of the stratospheric sulphate layer in vol- canically quiescent periods is controlled by the oxidation of COS.

For evaluation we also performed a simulation with a superimposed injection of $\mathrm{SO}_{2}$ at altitudes and latitudes corresponding to the distribution of observed Pinatubo aerosol in September 1991. The model correctly simulates the transformation to sulphate aerosol, including its optical properties. The removal of the volcanic aerosol in the first 6 months appears to be somewhat too fast as in earlier studies (e.g. Timmreck et al., 1999) due to sedimentation of coarse particles, showing the limitations of applying the 7 mode aerosol module GMXe in both the troposphere and stratosphere. A paper on these results and on the effects of recent tropical eruptions (Vernier et al., 2011) on the Junge layer is in preparation.

\section{Climate effects}

\subsection{Global warming potential}

Some trace constituents in the atmosphere, in particular halocarbons and COS, have infrared (IR) absorption bands in the 8-14 $\mu \mathrm{m}$ wavelength region, the atmospheric window, and as a consequence they can efficiently enhance the greenhouse effect. Gases such as $\mathrm{CO}_{2}$ and water vapour absorb at longer IR wavelengths, so that $60-80 \%$ of the radiation emitted in 

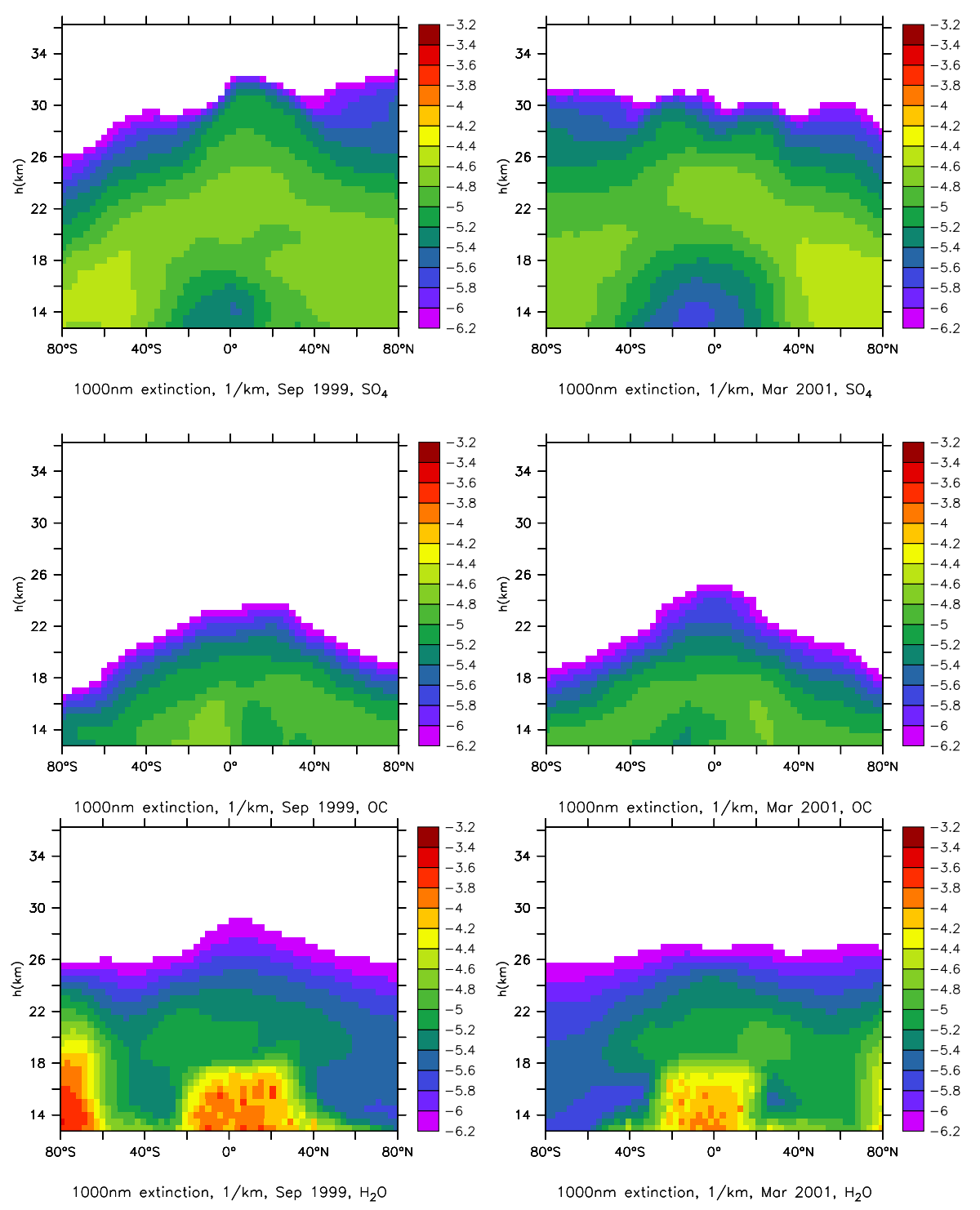

Fig. 8. Contribution of aerosol components to simulated total extinction (Fig. 7). OC is organic carbon.

the window region passes the atmosphere unattenuated. In fact, molecules with bonds between carbon, fluorine and sulphur are particularly efficient in absorbing this IR radiation, so that their increase contributes to heating of our planet. Overall, the efficiency of greenhouse warming of a molecule depends on the strength of its IR absorption bands as well as its concentration, the latter being determined by the sources and the atmospheric lifetime. To account for both the radiative forcing of a molecule and its long-term climate impact the concept of the global warming potential (GWP) has been developed, a metric that has been used in the Kyoto Protocol. The GWP is based on the time-integrated global mean radiative forcing of a pulse emission of a compound relative to that of the reference gas $\mathrm{CO}_{2}$. Here we present the GWP on a mass/mass basis for the time horizons $\Delta t$ of 20 and $100 \mathrm{yr}$, approximated by the following expression (Roehl et al., 1995): $\mathrm{GWP}_{\Delta t}=\frac{\mathrm{RF}_{\mathrm{COS}}}{\mathrm{RF}_{\mathrm{CO}_{2}}} \frac{\tau_{\mathrm{COS}}}{\tau_{\mathrm{CO}}} \frac{1-e^{-\Delta t / \tau} \mathrm{COS}}{1-e^{-\Delta t / \tau} \mathrm{CO}_{2}}$. This massbased GWP can be converted into the mole-based GWP by multiplying with the ratio of the molecular weights. The steady state GWP is calculated for $\Delta t \rightarrow \infty$, whereby the last term on the rhs approaches 1 . For the lifetime of COS we adopt $\tau_{\mathrm{COS}}=2 \mathrm{yr}$, while for $\tau_{\mathrm{CO}_{2}}$ a sum of exponential terms is applied, as recommended by the IPCC, leading to an effective lifetime of $\tau_{\mathrm{CO}_{2}} \approx 75 \mathrm{yr}$ for a time horizon of $\Delta t=100 \mathrm{yr}$. For the first term on the rhs, the (relative) radiative forcing (RF) of $1 \mathrm{~kg}$ of COS relative to $1 \mathrm{~kg}$ of $\mathrm{CO}_{2}$ added to the present atmosphere, we compute a value of 724 , applying our radiative convective model (Brühl and Crutzen, 1988). This model applies the broadband approach for the three infrared 
bands of COS at 522, 859 and $1047 \mathrm{~cm}^{-1}$ with bandstrengths $24.9,72.3$ and $24.4 \mathrm{~cm}^{-2} \mathrm{~atm}^{-1}$ using spectra from our laboratory (J. Crowley, personal communication, 2008). Overlap with other gases and the decrease of mixing ratio with altitude due to chemistry are taken into account. For the CFCs the calculated radiative forcing of this model is rather similar to ECHAM5. By inserting the above mentioned lifetimes we obtain a GWP of COS of 97 for $\Delta t=20 \mathrm{yr}$, and of 27 for $\Delta t=100 \mathrm{yr}$ (note that this translates into molar GWPs of 132 and 36 for time horizons of $\Delta t=20$ and $100 \mathrm{yr}$, respectively).

By using the model calculated forcing of $0.5 \mathrm{ppbv}$ COS of $0.008 \mathrm{~W} \mathrm{~m}^{-2}$ and the information from ice cores about the natural atmospheric mixing ratio of COS, being $70 \%$ of the present level, we calculate that the human-induced enhancement of COS exerts a radiative forcing of about $0.003 \mathrm{~W} \mathrm{~m}^{-2}$. As discussed above, the uptake by the biosphere limits the lifetime of COS in the atmosphere. Based on the chemical lifetime alone ( $35 \mathrm{yr})$ the GWP would be nearly 17 times higher for a time horizon of $\Delta t=100$. Of course, the biosphere-controlled lifetime also limits transport to the stratosphere where $\mathrm{COS}$ also exerts a radiative forcing.

The stratospheric breakdown of COS into $\mathrm{SO}_{2}$ and sulphuric acid is followed by the formation of aerosol particles that grow by the continued deposition of $\mathrm{H}_{2} \mathrm{SO}_{4}$ and coagulation. The latter process levels off at a steady state effective particle radius (i.e. surface area weighted) of approximately $0.3 \mu \mathrm{m}$ (SPARC, 2006), also because of sedimentation. Particles of this size effectively interact with solar radiation, because the solar spectrum has an energy maximum at a wavelength of about $0.5 \mu \mathrm{m}$. Hence the solar radiation scattering by sulphuric acid particles can substantially reduce the amount of energy that reaches the surface and exerts a negative radiative forcing. Note that even though the mean effective radius of the particles is 0.1 to $0.2 \mu \mathrm{m}$, some can be larger $(>0.6 \mu \mathrm{m})$ and also absorb solar near-infrared (IR) radiation, which locally warms the stratosphere and adds to the negative forcing in the troposphere. However, the latter effect is moderated by the presence of clouds and water vapour in the troposphere (which effectively absorb near-IR radiation). If the particles were even larger, notably $>2 \mu \mathrm{m}$, they would absorb terrestrial IR radiation and enhance the greenhouse effect. These radiative effects have been investigated in detail based on the measured and modelled impact of the Mt. Pinatubo eruption on the stratosphere (Minnis et al., 1993; Stenchikov et al., 1998). The observed global mean optical depth of the stratospheric aerosol was about 0.1 in the year following the eruption, and the associated net visible and IR radiative forcing was largely negative, about $-0.7 \mathrm{~W} \mathrm{~m}^{-2}$, except over the winter poles where the absence of solar radiation allowed the small longwave forcing effect to dominate. The Pinatubo aerosol caused a temporary global temperature decrease of about $0.5^{\circ} \mathrm{C}$ (McCormick et al., 1995). These data can be used here because the aerosol radiative forcing scales approximately with the optical depth, so that the climate effects by stratospheric COS can be derived.
The stratospheric sulphur loading by the Mt. Pinatubo eruption was $\approx 10 \mathrm{Mt} \mathrm{S}$, while the sulphur mass in the background stratospheric sulphate aerosol is about $0.15 \mathrm{MtS}$. The latter corresponds to a mean background aerosol optical depth of 0.003 . Since COS controls the abundance of the non-volcanic aerosol layer, we derive a negative radiative forcing of $-0.02 \mathrm{~W} \mathrm{~m}^{-2}$. This back of the envelope number agrees with the global average of the forcing simulated by EMAC at the top of the atmosphere in Fig. 9. In EMAC this quantity was calculated diagnostically from additional calls of the radiation module with stratospheric aerosol above $100 \mathrm{hPa}$ only and without any aerosol. It should be emphasized that this is not really a "forcing" of the COS-derived aerosol because it reflects the long-term background condition of the atmosphere, which is to a large degree natural. Again we can use the information from ice cores about preindustrial COS levels (Montzka et al., 2004), assuming that the difference with present-day levels is anthropogenic, being about $30 \%$ (Table 1). It follows that the human-induced enhancement of the background stratospheric aerosol exerts a negative radiative forcing of about $-0.007 \mathrm{~W} \mathrm{~m}^{-2}$, which actually exceeds the positive forcing of COS by more than a factor of two. Since the e-folding lifetime of stratospheric aerosol is about one year (thus half of $\tau_{\mathrm{COS}}$ ) the global "cooling" potential of COS through stratospheric aerosol formation is equivalent to the above derived GWP. Therefore, if we account for indirect chemical effects in GWP calculations, also customary for gases such as methane (IPCC, 2007), it follows that COS has almost no net climate impact. This also applies to the precursor gas $\mathrm{CS}_{2}$, which has a very short lifetime and an insignificant GWP.

The average forcing by stratospheric background aerosol at $185 \mathrm{hPa}$ (approximately the tropopause) is $-0.09 \mathrm{~W} \mathrm{~m}^{-2}$. A large fraction of that is due to organic carbon aerosol (including black carbon) near the tropical tropopause. Figure 9 shows that this forcing is strongly influenced by the large local variability due to clouds and surface albedo. The largest negative forcing is in subtropical regions with clear skies and a low surface albedo, i.e. over the oceans. Figure 9 demonstrates also that the shortwave forcing of stratospheric aerosol at the top of the atmosphere differs considerably from that at the tropopause.

\subsection{Uncertainties}

It appears that the EMAC model tends to overestimate the transport of particulate sulphate and $\mathrm{SO}_{2}$ from the tropics to midlatitudes in the lowermost stratosphere especially in the summer hemisphere. This leads to too fast removal of stratospheric aerosol. Assuming that this model deficiency is responsible for about half of the difference to aerosol observations, the negative forcing of aerosol related to anthropogenic COS would be about $-0.0085 \mathrm{~W} \mathrm{~m}^{-2}$ with the consequence that the cooling would slightly dominate the greenhouse warming. According to T. Johnson of PNNL the 

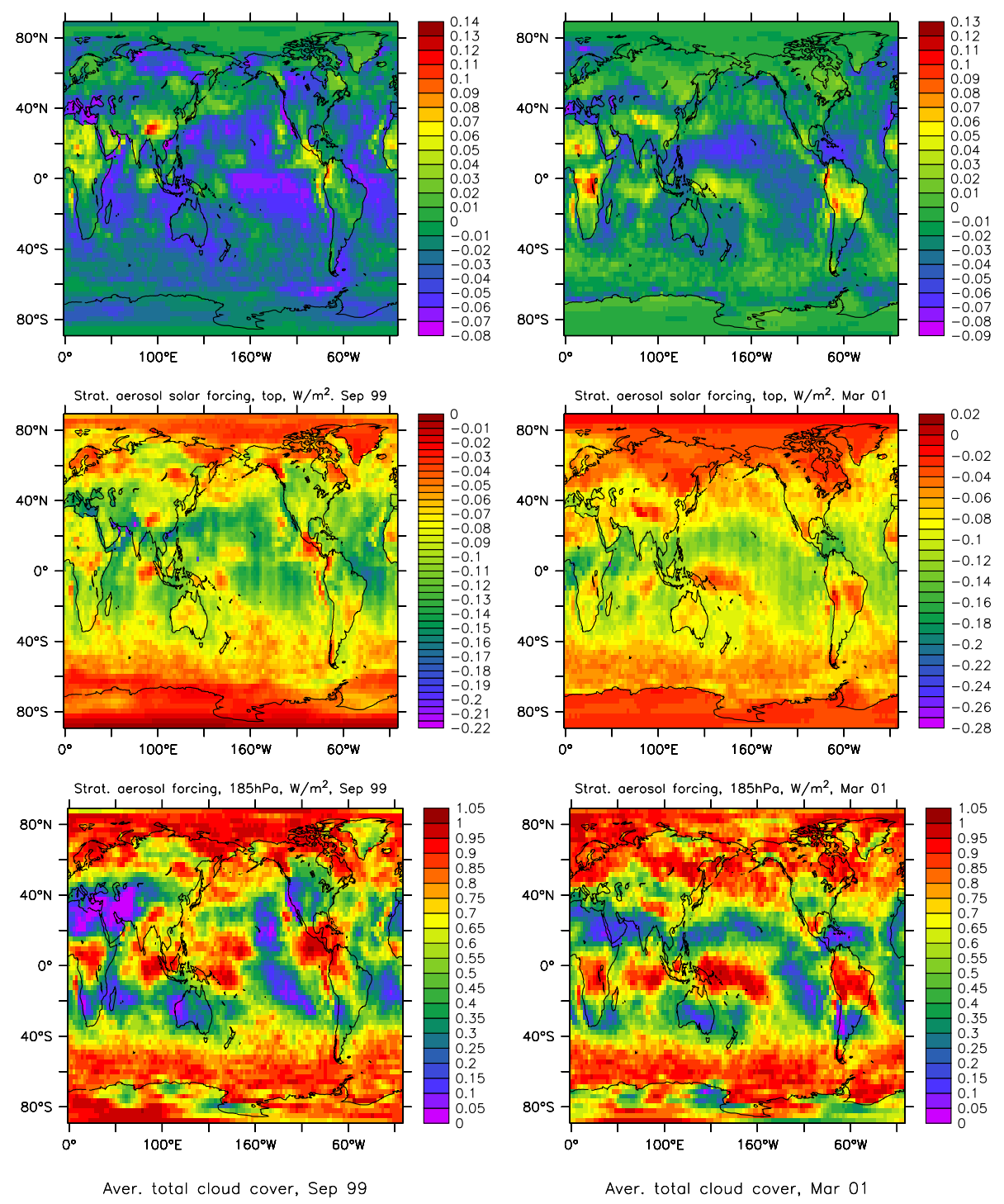

Fig. 9. Solar radiative forcing of stratospheric aerosol (above $110 \mathrm{hPa}$ ) at the top of the atmosphere (upper panels) and at $185 \mathrm{hPa}$ (middle panels). The lower panels show the average total effective cloud cover in the troposphere.

bandstrengths of COS in the infrared window used for this study might be about $40 \%$ high. Taking this into account, the infrared forcing of anthropogenic COS would be reduced to $0.002 \mathrm{~W} \mathrm{~m}^{-2}$, leading to a dominance of the cooling from the induced aerosol. This would also reduce the direct GWP of COS to 58 and 16 for the time horizons of 20 and $100 \mathrm{yr}$. However, there are only very few measurements of IR COSspectra available.

Another source of uncertainty is the wide range of refractive indices for water soluble aerosol available in the literature. For radiative forcing there are often compensating effects from different spectral regions so that the net effect is rather small (of the order of $10 \%$ ), however, for comparison with satellite extinction data, it is important to use spec- tra of refractive indices consistent with the retrieval. Here it should be distinguished between stratospheric and tropospheric aerosol, but using the refractive indices of ammonium sulphate can be a good compromise (if the focus is not on details in the near infrared). Nevertheless, there is a need for a new compilation of aerosol refractive indices to reduce uncertainties.

\section{Conclusions}

Carbonyl sulphide, an efficient greenhouse gas, is the most abundant sulphur gas in the atmosphere. Its anthropogenic emissions and that of $\mathrm{CS}_{2}$, the latter being converted into COS, contribute approximately $30 \%$ to the global COS 
mixing ratio of about 0.5 ppbv. By applying surface measurements of COS from a global network of 12 stations as boundary conditions, our chemistry-climate model reproduces the atmospheric COS cycle well. The observational database for COS, $\mathrm{CS}_{2}$ and $\mathrm{SO}_{2}$, especially for the tropical tropopause layer (12-18 km altitude), is presently insufficient for a conclusive evaluation of the sulphur cycle and associated aerosol production in the background stratosphere, i.e. during volcanically quiescent periods. Nevertheless, we present compelling evidence that COS plays a controlling role, as stated by Crutzen (1976) and Turco et al. (1980). Our EMAC model results indicate that the COS controlled sulphur flux into the stratosphere is about $0.15 \mathrm{MtS} \mathrm{yr}^{-1}$ with about $0.035 \mathrm{MtS} \mathrm{yr}^{-1}$ converted to aerosol, whereas in previous evaluations the same flux of $\mathrm{S}$ was obtained assuming direct transport of $\mathrm{SO}_{2}, \mathrm{CS}_{2}$ and $\mathrm{H}_{2} \mathrm{~S}$ across the tropical tropopause. We consider the latter assumption to be unlikely and not needed to explain observations of the background stratospheric aerosol. Our chemistry climate model EMAC with aerosol module is able to reproduce most of the features observed by SAGE, including the modulation of stratospheric aerosol by the QBO and the seasonal effects, and non-sulphate compounds. It also reproduces $\mathrm{SO}_{2}$ in the upper stratosphere observed by ATMOS on the Space Shuttle. We compute the climate effects and the global warming potential (GWP) of COS, which accounts for the radiative forcing as well as the atmospheric lifetime. The direct IR radiative forcing by $1 \mathrm{~kg}$ of COS, i.e. the enhancement of the greenhouse effect, is 724 times that of $1 \mathrm{~kg} \mathrm{CO}_{2}$, using our chemical radiative convective model. Based on a $30 \%$ contribution of human-induced emissions to COS in the present atmosphere, the IR radiative forcing of anthropogenic COS is $0.003 \mathrm{~W} \mathrm{~m}^{-2}$. The GWP of COS over time horizons of 20 and $100 \mathrm{yr}$ is $\operatorname{GWP}(20 \mathrm{yr})=97$ and $\operatorname{GWP}(100 \mathrm{yr})=27$, respectively. However, through its contribution to stratospheric aerosols COS also exerts a radiative cooling forcing, which amounts to about $-0.007 \mathrm{~W} \mathrm{~m}^{-2}$ in EMAC, more than twice the warming forcing. Since the atmospheric lifetime of COS is about $2 \mathrm{yr}$ and the COS-derived aerosol lifetime time only $1 \mathrm{yr}$, the opposing climate effects tend to cancel and the net GWP of COS is insignificant. This also applies to $\mathrm{CS}_{2}$ in view of its very short atmospheric lifetime of a few days and its partial conversion to COS. Taking into account that the COS IR spectra used in this study are at the high end, the cooling effect of COS-derived aerosol might dominate.

\section{Supplement related to this article is available online at: http://www.atmos-chem-phys.net/12/1239/2012/ acp-12-1239-2012-supplement.pdf.}

Acknowledgements. We thank Kirsty Pringle of the University of Leeds, UK, who contributed to the development of the aerosol module. Also we thank our colleagues of MPI for Chemistry, Francois Benduhn for providing his yet unpublished sedimentation scheme and Swen Metzger for the aerosol thermodynamics scheme
EQSAM. We thank M. Barkley of University of Leicester, UK, and P. Bernath of University of York, UK, for providing the ASCII-data of their Fig. 3 on ACE-FTS-COS observations. We further thank Lamont Poole and Larry Thomason of NASA Langley Research Center, Hampton, USA, for their advice on SAGE data. The research leading to these results has received funding from the European Research Council under the European Union's Seventh Framework Programme (FP7/2007-2013)/ERC grant agreement no. 226144.

The service charges for this open access publication have been covered by the Max Planck Society.

Edited by: P. Stier

\section{References}

Andersen, S.B., Weatherhead, E. C., Stevermer, A., Austin, J., Brühl, C., Fleming, E. L., de Grandpre, J., Grewe, V., Isaksen, I., Pitari, G., Portmann, R. W., Rognerud, B., Rosenfield, J. E., Smyshlayev, S., Nagashima, T., Velders, G. J. M., Weisenstein, D. K., and Xia, J.: Comparison of recent modeled and observed trends in total column ozone, J. Geophys. Res., 111, D02303, doi:10.1029/2005JD006091, 2006.

Andreae, M. O.: Ocean-atmosphere interactions in the global biogeochemical sulphur cycle, Marine Chem., 30, 1-29, 1990.

Aydin, M., Williams, M. B., Tatum, C., and Saltzman, E. S.: Carbonyl sulfide in air extracted from a South Pole ice core: a 2000 year record, Atmos. Chem. Phys., 8, 7533-7542, doi:10.5194/acp-8-7533-2008, 2008.

Bandy, A. R., Thornton, D. C., Scott, D. L., Lalevic, M., Lewis, E. E., and Driedger III, A. R.: A time series for carbonyl sulfide in the Northern Hemisphere, J. Atmos. Chem., 14, 527-534, 1992.

Barkley, M. P., Palmer, P. I., Boone, C. D., Bernath, P. F., and Suntharalingam, P.: Global distributions of carbonyl sulfide in the upper troposphere and stratosphere, Geoph. Res. Lett., 35, L14810, doi:10.1029/2008GL034270, 2008.

Blake, N.J., Streets, D. G., Woo, J.-H., Simpson, I. J., Green, J., Meinardi, S., Kita, K., Atlas, E., Fuelberg, H. E., Sachse, G., Avery, M. A., Vay, S. A., Talbot, R. W., Dibb, J. E., Bandy, A. R., Thornton, D. C., Rowland, F. S., and Blake, D. R.: Carbonyl sulfide and carbon disulfide: Large-scale distributions over the western Pacific and emissions from Asia during TRACE-P, J. Geophys. Res., 109, D15S05, doi:10.1029/2003JD004259, 2004.

Brühl, C., and Crutzen, P. J.: Scenarios of possible changes in atmospheric temperatures and ozone concentrations due to man's activities, estimated with a one-dimensional coupled photochemical climate model, Clim. Dynam., 2, 173-203, 1988.

Campbell, J. E., Carmichael, G. R., Chai, T., Mena-Carrasco, M., Tang, Y., Blake, D. R., Blake, N. J., Vay, S. A., Collatz, G. J., Baker, I., Berry, J. A., Montzka, S. A., Sweeney, C., Schnoor, J. L., and Stanier, C. O.: Photosynthetic control of atmospheric carbonyl sulfide during the growing season, Science, 322, 10851088, 2008.

Chin, M. and Davis, D. D.: Global sources and sinks of OCS and $\mathrm{CS}_{2}$ and their distributions, Global Biogeochem. Cy., 7, 321337, 1993.

Crutzen, P. J.: The possible importance of CSO for the sulphate layer of the stratosphere, Geophys. Res. Lett., 3, 73-76, 1976. 
Crutzen, P. J., Heidt, L. E., Krasnec, J. P., Pollock, W. H., and Seiler, W.: Biomass burning as a source of atmospheric gases: $\mathrm{CO}, \mathrm{H}_{2}$, $\mathrm{N}_{2} \mathrm{O}, \mathrm{NO}, \mathrm{CH}_{3} \mathrm{Cl}$, and COS, Nature, 282, 253-256, 1979.

Giorgetta, M. A., Manzini, E., Roeckner, E., Esch, M., and Bengtsson, L.: Climatology and forcing of the quasi-biennial oscillation in the MAECHAM5 model, J. Climate, 19, 3882-3901, 2006.

Grainger, R. G., Lambert, A., Rodgers, C. D., Taylor, F. W., and Deshler, T.: Stratospheric aerosol effective radius, surface area and volume estimated from infrared measurements, J. Geophys. Res., 100, 16507-16518, 1995.

Grooß, J. U., Brühl, C., and Peter, T.: Impact of aircraft emissions on tropospheric and stratospheric ozone Part I: Chemistry and 2-D model results, Atmos. Environ., 32, 3173-3184, 1998.

Hervig, M. E., Russell III, J. M., Gordley, L. L., Park, J. H., Drayson, S. R., and Deshler, T.: Validation of aerosol measurements from the Halogen Occultation Experiment, J. Geophys. Res., 101, 10267-10275, 1996.

Hintze, P. E., Kjaergaard, H. G., Vaida, V., and Burkholder, J. B.: Vibrational and electronic spectroscopy of sulfuric acid vapor, J. Phys. Chem. A, 107, 1112-1118, 2003.

Intergovernmental Panel on Climate Change (IPCC), Climate Change 2007: The Physical Science Basis, edited by: Solomon, S., Qin, D., Manning, M., Marquis, M., Averyt, K. B., Tignor, M., Miller, H. L., and Chen, Z., Cambridge University Press, Cambridge, UK, and New York, NY, USA, 1-234, 2007.

Jöckel, P., Tost, H., Pozzer, A., Brühl, C., Buchholz, J., Ganzeveld, L., Hoor, P., Kerkweg, A., Lawrence, M. G., Sander, R., Steil, B., Stiller, G., Tanarhte, M., Taraborelli, D., van Aardenne, J., and Lelieveld, J.: The atmospheric chemistry general circulation model ECHAM5/MESSy: Consistent simulation of ozone from the surface to the mesosphere, Atmos. Chem. Phys., 6, 50675104, doi:10.5194/acp-6-5067-2006, 2006.

Junge, C. E., Chagnon, C. W., and Manson, J. E.: Stratospheric aerosols, J. Meteorol., 18, 81-108, 1961.

Kettle, A. J., Kuhn, U., von Hobe, M., Kesselmeier, J., and Andreae, M. O.: Global budget of atmospheric carbonyl sulphide: Temporal and spatial variations of the dominant sources and sinks, J. Geophys. Res., 107, 4658, doi:10.1029/2002JD002187, 2002.

Kuhn, U., Ammann, C., Wolf, A., Meixner, F. X., Andreae, M. O., and Kesselmeier, J.: Carbonyl sulphide exchange on an ecosystem scale: soil represents a dominant sink for atmospheric COS, Atmos. Environ., 33, 995-1008, 1999.

Lelieveld, J., Roelofs, G. J., Ganzeveld, L., Feichter, J., and Rodhe, H.: Terrestrial sources and distribution of atmospheric sulphur, Phil. Trans. R. Sic. London, B, 352, 149-158, 1997.

Lelieveld, J., Brühl, C., Jöckel, P., Steil, B., Crutzen, P. J., Fischer, H., Giorgetta, M. A., Hoor, P., Lawrence, M. G., Sausen, R., and Tost, H.: Stratospheric dryness: model simulations and satellite observations, Atmos. Chem. Phys., 7, 1313-1332, doi:10.5194/acp-7-1313-2007, 2007.

McCormick, M. P., Thomason, L. W., and Trepte, C. R.: Atmospheric effects of the Mt. Pinatubo eruption, Nature, 373, 399404, 1995.

Minnis, P., Harrison, E. F., Stowe, L. L., Gibson, G. G., Denn, F. M., Doelling, D. R., and Smith, Jr., W. L.: Radiative climate forcing by the Mount Pinatubo eruption, Science, 259, 1411-1415, 1993.

Mihalopoulos, N., Putaud, J. P., Nguyen, B. C., and Belviso, S.: Annual variation of atmospheric carbonyl sulfide in the marine atmosphere in the southern Indian Ocean, J. Atmos. Chem., 13,
73-82, 1991.

Mills, M. J., Toon, O. B., and Thomas, G. E.: Mesospheric sulfate aerosol layer, J. Geophys. Res., 110, D24208, doi:10.1029/2005JD006242, 2005.

Montzka, S. A., Aydin, M., Battle, M., Butler, J. H., Saltzman, E. S., Hall, B. D., Clarke, A. D., Mondeel, D., and Elkins, J. W.: A 350-year atmospheric history for carbonyl sulfide inferred from Antarctic firn air and air trapped in ice, J. Geophys. Res., 109, D22302, doi:10.1029/2004JD004686, 2004.

Montzka, S. A., Calvert, P., Hall, B. D., Elkins, J. W., Conway, T. J., Tans, P. P., and Sweeney, C.: On the global distribution, seasonality, and budget of atmospheric carbonyl sulfide and some similarities with $\mathrm{CO}_{2}$, J. Geophys. Res., 112, D09302, doi:10.1029/2006JD007665, 2007.

Mu, Y., Geng, C., Wang, M., Wu, H., Zhang, X., and Jiang, G.: Photochemical production of carbonyl sulphide in precipitation, $\mathrm{J}$. Geophys. Res., 109, D13301, doi:10.1029/2003JD004206, 2004.

Murphy, D. M., Cziczo, D. J., Hudson, P. K., and Thomson, D. S.: Carbonaceous material in aerosol particles in the lower stratosphere and tropopause region, J. Geophys. Res., 112, D04203, doi:10.1029/2006JD007297, 2007.

Notholt, J., Kuang, Z., Rinsland, C. P., Toon, G. C., Rex, M., Jones, N., Albrecht, T., Deckelmann, H., Krieg, J., Weinzierl, C., Bingemer, H., Weller, R., and Schrems, O.: Enhanced upper tropical tropospheric COS: Impact on the stratospheric aerosol layer, Science, 300, 307-310, 2003.

Pringle, K. J., Tost, H., Message, S., Steil, B., Giannadaki, D., Nenes, A., Fountoukis, C., Stier, P., Vignati, E., and Lelieveld, J.: Description and evaluation of GMXe: a new aerosol submodel for global simulations (v1), Geosci. Model Dev., 3, 391412, doi:10.5194/gmd-3-391-2010, 2010.

Rinsland, C. P., Gunson, M. R., Ko, M. K. W., Weisenstein, D. W., Zander, R., Abrams, M. C., Goldman, A., Sze, N. D., and Yue, G. $\mathrm{K}$.: $\mathrm{H}_{2} \mathrm{SO}_{4}$ photolysis: A source of sulfur dioxide in the upper stratosphere, Geophys. Res. Lett., 22, 1109-1112, 1995.

Rinsland, C. P., Goldman, A., Mahieu, E., Zander, R., Notholt, J., Jones, N. B., Griffith, D. W. T., Stephen, T. M., and Chiou, L. S.: Ground-based infrared spectroscopic measurements of carbonyl sulfide: Free tropospheric trends from a 24-year time series of solar absorption measurements, J. Geophys. Res., 107, 4657, doi:10.1029/2002JD002522, 2002.

Rinsland, C. P., Chiou, L., Mahieu, E., Zander, R., Boone, C. D., Bernath, P. F.: Measurements of long-term changes in atmospheric OCS (carbonyl sulfide) from infrared solar observations, J. Quant. Spectrosc. Ra., 109, 2679-2686, 2008.

Robock, A.: Volcanic eruptions and climate, Rev. Geophys., 38, 191-219, 2000.

Roeckner, E., Brokopf, R., Esch, M., Giorgetta, M., Hagemann, S., Kornblueh, L., Manzini, E., Schlese, U., and Schulzweida, U., Sensitivity of simulated climate to horizontal and vertical resolution in the ECHAM5 atmosphere model, J. Climate, 19, 37713791, 2006.

Roehl, C. M., Boglu, D., Brühl, C., and Moortgat, G. K.: Infrared band intensities and global warming potentials of $\mathrm{CF}_{4}, \mathrm{C}_{2} \mathrm{~F}_{6}$, $\mathrm{C}_{3} \mathrm{~F}_{8}, \mathrm{C}_{4} \mathrm{~F}_{10}, \mathrm{C}_{5} \mathrm{~F}_{12}$, and $\mathrm{C}_{6} \mathrm{~F}_{14}$, Geophys. Res. Lett., 22, 815$818,1995$.

Sander, R., Kerkweg, A., Jöckel, P., and Lelieveld, J.: Technical note: The new comprehensive atmospheric chemistry module MECCA, Atmos. Chem. Phys., 5, 445-450, doi:10.5194/acp-5- 
445-2005, 2005.

Sander, S. P., Friedl, R. R., Golden, D. M., Kurylo, M. J., Moortgat, G. K., Keller-Rudek, H., Wine, P. H., Ravishankara, A. R., Kolb, C. E., Molina, M. J., Finlayson-Pitts, B. J., Huie, R. E., and Orkin, V. L.: Chemical Kinetics and Photochemical Data for Use in Atmospheric Studies, Evaluation Number 15, JPL Publication 06-2, Jet Propulsion Laboratory, Pasadena, USA, 2006.

Sandoval-Soto, L., Stanimirov, M., von Hobe, M., Schmitt, V., Valdes, J., Wild, A., and Kesselmeier, J.: Global uptake of carbonyl sulfide (COS) by terrestrial vegetation: Estimates corrected by deposition velocities normalized to the uptake of carbon dioxide $\left(\mathrm{CO}_{2}\right)$, Biogeosciences, 2, 125-132, doi:10.5194/bg-2-125-2005, 2005.

Stratospheric Processes and their Role in Climate (SPARC), Assessment of Stratospheric Aerosol Particles, edited by: Thomason, L. and Peter, T., SPARC Report No. 4, WMO/WCRP, 2006.

Steinbacher, M., Bingemer, H. G., and Schmidt, U.: Measurements of the exchange of carbonyl sulfide (OCS) and carbon disulfide $\left(\mathrm{CS}_{2}\right)$ between soil and atmosphere in a spruce forest in central Germany, Atmos. Environ., 38, 6043-6052, 2004.

Stenchikov, G. L., Kirchner, I., Robock, A., Graf, H.-F., Antuña, J. C., Grainger, R. G., Lambert, A., and Thomason, L.: Radiative forcing from the 1991 Mount Pinatubo volcanic eruption, J. Geophys. Res., 103, 13837-13857, 1998.

Sturges, W. T., Penkett, S. A., Barnola, J.-M., Chappellaz, J., Atlas, E., and Stroud, V.: A long-term record of carbonyl sulfide (COS) in two hemispheres from firn air measurements, Geophys. Res. Lett., 28, 4095-4098, 2001.

Thomason, L. W., Poole, L. R., and Deshler, T.: A global climatology of stratospheric aerosol surface area density deduced from Stratospheric Aerosol and Gas Experiment II measurements: 1984-1994, J. Geophys. Res., 102, 8967-8976, 1997.

Thomason, L. W., Burton, S. P., Luo, B.-P., and Peter, T.: SAGE II measurements of stratospheric aerosol properties at non-volcanic levels, Atmos. Chem. Phys., 8, 983-995, doi:10.5194/acp-8-9832008, 2008.
Thornton, D. C., Bandy, A., Blomquist, B., Driedger, A., and Wade, T.: Sulfur dioxide distributed over the Pacific Ocean 1991-1996, J. Geophys. Res., 104, 5845-5854, doi:10.1029/1998JD100048, 1999.

Timmreck, C., Graf, H.-F., and Feichter, J.: Simulation of Mt. Pinatubo volcanic aerosol with the Hamburg climate model ECHAM4, Theor. Appl. Climatol., 62, 85-108, 1999.

Turco, R. P., Whitten, R. C., Toon, O. B., Pollack, J. B., and Hamill, P.: OCS, stratospheric aerosols and climate, Nature, 283, 283285, 1980.

Vaida, V., Kjaergaard, H. G., Hintze, P. E., Donaldson, D. J.: Photolysis of sulfuric acid vapor by visible solar radiation, Science, 299, 1566-1568, 2003.

Van Diest, H. and Kesselmeier, J.: Soil atmosphere exchange of carbonyl sulfide (COS) regulated by diffusivity depending on waterfilled pore space, Biogeosciences, 5, 475-483, doi:10.5194/bg-5475-2008, 2008.

Vehkamäki, H., Kulmala, M., Napari, I., Lehtinen, K. E. J., Timmreck, C., Noppel, M., and Laaksonen, A.: An improved parameterization for sulfuric acid-water nucleation rates for tropospheric and stratospheric conditions, J. Geophys. Res., 107, 4622, doi:10.1029/2002JD002184, 2002.

Vernier, J.-P., Thomason, L. W., Pommereau, J. P., Bourassa, A., Pelon, J., Garnier, A., Hauchecorne, A., Blanot, L., Trepte, C., Degenstein, D., and Vargas, F.: Major influence of tropical volcanic eruptions on the stratospheric aerosol layer during the last decade, Geophys. Res. Lett., 38, L12807, doi:10.1029/2011GL047563, 2011.

Watts, S. F.: The mass budgets of carbonyl sulfide, dimethyl sulfide, carbon disulfide and hydrogen sulfide, Atmos. Environ., 34, 761779, 2000.

Weisenstein, D. K., Yue, G., Ko, M., Sze, N.-D., Rodriguez, J., and Scott, C.: A two-dimensional model of sulfur species and aerosols, J. Geophys. Res., 102, 13019-13035, doi:10.1029/97JD00901, 1997. 